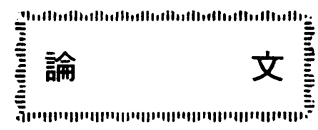

\title{
受光面積の大きいサーモパイルの交流動作特性
}

\author{
専門会員 中川 靖夫* 専門会員大谷 文雄*
}

\section{Characteristics of the Relatively Large Aparture Thermopile on Chopping Operation}

\author{
Yasuo Nakagawa (Fellow Member) Fumio Ohotani (Fellow Member) \\ (Department of Electronic Engineering, Faculty of Engineering Saitama University)
}

\begin{abstract}
Very low frequency chopping operation of thermopile, which has relatively large aparture and time constant, has been studied and compared with dc mode.

Amplification of very low frequency $(0.1 \sim 0.3 \mathrm{~Hz})$ is carried out with a digital lock-in system and a usual dc amplifier.

Under chopping operation, apparent sensitivity falls with frequency increasing, but noise are also reduced, so detectivity at $0.2 \mathrm{~Hz}$ is $10^{7} \mathrm{~W}^{-1} \mathrm{~cm} \mathrm{~Hz} \mathrm{H}^{-1 / 2}$, which is 1.2 times greater than dc mode. Drift free operation is realised with dc drift component cut off. Linearity and uniformity of receiving area are similar to dc mode.

Temperature coefficient of sensitivity has been improved and obtained value is $-0.15 \% /{ }^{\circ} \mathrm{C}$ at $19 \sim 29^{\circ} \mathrm{C}$ (about one half of that in dc mode).
\end{abstract}

\section{1. ま え がき}

感度が波長に依存しないで，放射の絶対量を測定できる検出器 としては，気中形のサーモパイルが古くから用いられてきてお り，最近ではレーザなどの放射出力計としてもかなり普及してい る.サーモパイルは受光面が十分黒化してあれば分光感度を広い 波長範囲で一定にできるが，感度そのものは一般にかなり低く、 検出能力は $\mathrm{Si}$ ホトセルよりも2〜3けた劣る。また，ある程度， 受光面積の大きいものは応答速度が遅く, 直流的に使用するため ゼロ点移動（ドリフト）が大きい. ドリフトの原因は主として周 囲の気温のゆっくりした変動や，照射によるヶースの温度上昇な どであり，微小放射（たとえば $10^{-5} \mathrm{~W} \cdot \mathrm{cm}^{-2}$ 以下）の測定ではそ
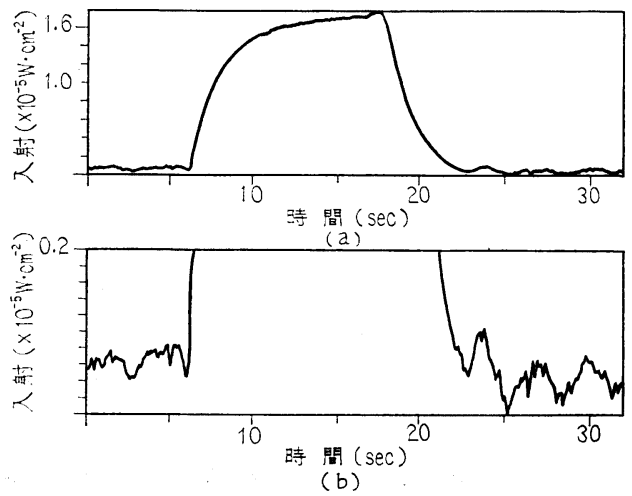

図1サーモパイ㨁流動作での答とだ口点移動の例

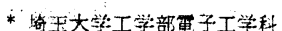

れが無視できない大きさとなって，ゼロ点チェックをひんぱんに 行なう必要が生ずる。とくに，空調（冷暖房）を行なっている室 内では，温度変動によるドリフトに送風の気流で生ずる部分的な 気圧，温度の変化が加算されて測定の重大な障害となる ${ }^{1)}$ (図 1 , 図 2).

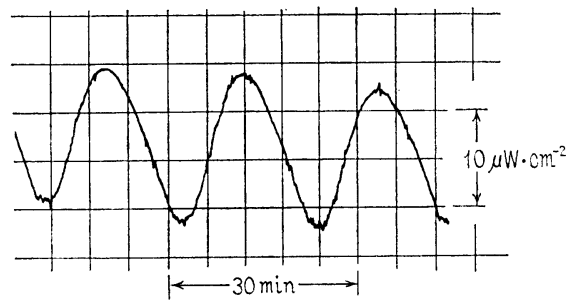

図 2 サーモハイイルDC動作の空調使用時のドリフト $\left(24 \pm 11^{\circ} \mathrm{C}\right)$

このような原因によるドリフト，ノイズ（ゆらぎ）を排除する には，入射を断続（チョッピング）させる交流動作が有効なこと はよく知られており，サーモパイルでも薄膜の真空封じ形のよう な小受光面積で，応答速度の速いものは $\mathrm{AC}$ 動作で使用するのが 普通である。このような小受光面積（たとえば $2 \times 2 \mathrm{~mm}$ ）のサ 一モパイルは集光の可能な分光測定などにはよく用いられる. 父 流動作はドリフト・ノイズの除去にはきわめて有利ではあるが， チョッパや増幅系などの安定性や精度の点から, 絶対量の測定を 高精度で行なうのは困難であり，また，集光系を用いるとすると それによる誤差も生じ得る。したがって，広がっている放射の場 での絶対測定を行ならときや，分光測定です受光器の分光感度の 精密測定のようにある程度大きな受光面積が必要な場合には，た 


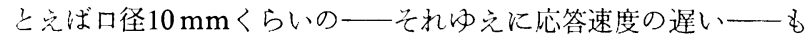
のを直流動作で使用せざるを得ず，その場合には前述したドリフ ト・ノイズによる測定の困難さがさけられないことになる。

筆者らはこのような問題を解決するために, 従来交流動作を全 く考虑していなかった $\mathrm{Ag}-\mathrm{Bi}$ 16対円形口径 $9.5 \phi$, 時定数 $2 \mathrm{~s}$ の サーモパイルについて交流動作を検討した。 その結果, 交流動作 はチョッピング周波数を $0.2 \mathrm{~Hz}$ 程度にとれば実用可能であって, 検出能力は直流動作の理想的状態と同等以上で, 空調その他の外 的騒乱に上るドリフトを事先上:ゼロにできることがわかり，高精 度の測定が容易に行なるるるよたになったので報告したい。

\section{2. 受光面皘の大きいサーモパイルの応答と雑音}

\section{1 応答と周波数特性}

試料として用いたサーモバイルは Eppley 製形父中形で，放 射測定によく使われるものである。表 1 とその定格などを示す。

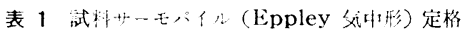

\begin{tabular}{|c|c|c|}
\hline H' & it & 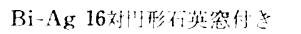 \\
\hline 7 & 优 & 金 装 \\
\hline 殸 & $16 *$ & $0.19 \mu \mathrm{V} \cdot u \mathrm{~W}^{-1} \cdot \mathrm{cm}^{2}\left(19^{\prime} \mathrm{C}\right)$ \\
\hline 带 & 炎: 消 情 & $9.5 \mathrm{c}\left(0.71 \mathrm{~cm}^{2}\right)$ \\
\hline $\mathrm{H}_{\mathrm{j}}$ & 动 数 & $2 \mathrm{~s}$ \\
\hline 的 & 新抵抗 & $25 \Omega$ \\
\hline & NEI* & $1.2 \times 10^{-7} \mathrm{~W} \cdot \mathrm{cm}^{-2} \cdot \mathrm{Hz}^{-1 / 2}$ \\
\hline his & 疼 保 数* & $-0.4 \% / 1^{\circ} \mathrm{C}\left(16 \sim 24^{\circ} \mathrm{C}\right)$ \\
\hline
\end{tabular}

応答特性は図 1 (a)からわかるとおりで，99\%出力に達する時間 は約 12 秒である（公称時定数 $2 \mathrm{~s}$ ). 入射の断続周波数を変化さ せたときの応答の振幅（p-p值）は図3のと打りである.この ときの入射は方形波であるが，出力は $0.1 \mathrm{~Hz}$ 以上では正弦波に 近くなる。これはサーモパイルが電気的には高域しゃ断フィルタ となるためである。皇机克，実効値としての出力(基本波成分) は方形波出力の之きは $\mathrm{p}-\mathrm{p}$ 值の $\sqrt{2} / \pi$ であるが，正弦波のとき には $1 / 2 \sqrt{ } 2$ となる。交流感度 $S_{a}$ を(1)式のように定義すると,

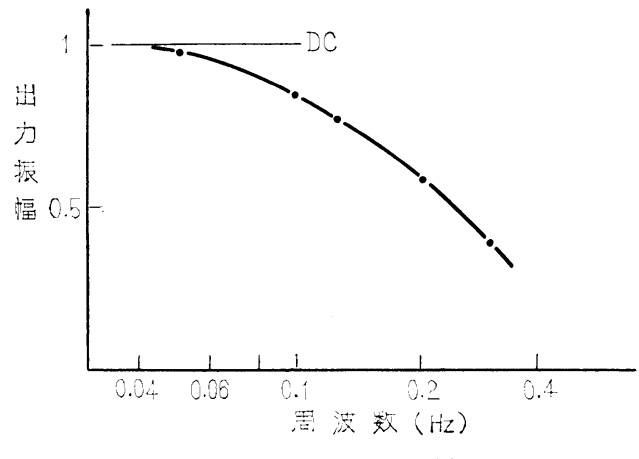

図 3 試料サーモパイ几の周波数特珄

この試料では $0.25 \mathrm{~Hz}$ で振幅が直流応答の $1 / 2$ になるので, 感度 は直流の $36 \%$ になる。

$$
S_{a}=V_{r m s} / 0.5 E_{p-p} \quad\left(\mathrm{~V} \cdot \mathrm{W}^{-1}\right) \cdot
$$

$E_{p-p}:$ 入射断続パワーの $\mathrm{p}-\mathrm{p}$ 值 (方形波)

$V_{r m t}$ : 出力 $\mathrm{p}-\mathrm{p}$ 値 $\times \sqrt{ } 2 / \pi$ (方形波), $\times 1 / 2 \sqrt{2}$ (正弦波)

\section{2 雑 音 特 性}

直流動作の状態で, ある程度の外部騒乱の影響を含む雑音（， イズ）をYHP 5420A ディジタル・シグナル・アナライザで解析 した. 雑音のスペクトラムの例を図 4 に示す. 雑音は白色成分 と $1 / \mathrm{f}$ 成分の混合とみられ, $1 / \mathrm{f}$ 成分は $0.2 \mathrm{~Hz}$ くらいから目立っ てくる.また， $0.25 \mathrm{~Hz}$ 付近には固有ノイズ（共振）が多少ある

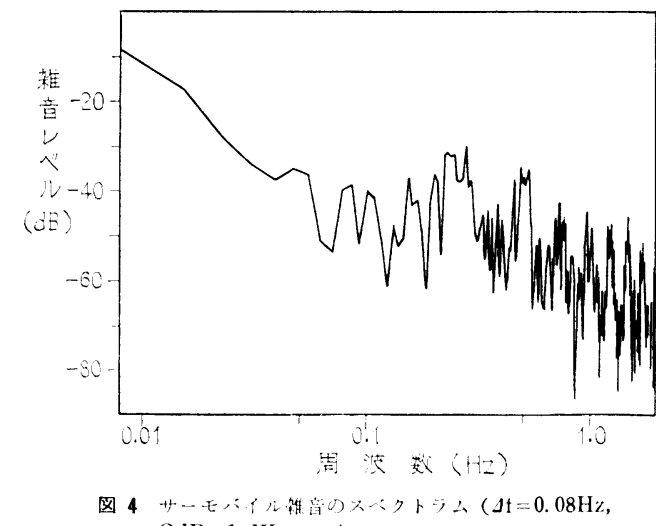

$\mathrm{OdB}=1 \mu \mathrm{W} \cdot \mathrm{cm}^{-2}$ )

らしいことが数回のくり返し測定から認められた。 1/f 成分はド リフトが主体と思われ，0.02 Hz 以下では相当大きくなってい る. $0.1 \mathrm{~Hz}$ 以上での雑音のレベルは, 帯域幅を $1 \mathrm{~Hz}$ としたとき 入力换算で $10^{-7} \mathrm{~W} \cdot \mathrm{cm}^{-2}$ 程度と考㝋られた．したがって $1 / \mathrm{f}$ 成分 （ドリフト）が除去できて，雑音レベルがこの程度であるならば 交流動作は卜分に利用洒值があると考兄た。

\section{3 交流動作の条件}

以上の測定結果からみた，このサーモバイルの交流動作の条件 は次のようになる。

（1）下限周波数は，1/f 雑音の増加と奏用測定時間を考虑与る と $0.1 \mathrm{~Hz}$ 程度.

(2) 上限周波数は感度の周波数特性からみて $0.3 \mathrm{~Hz}$ 程度.

(3) $1 / \mathrm{f}$ 雑音のしゃ断には低域しゃ断フィルタ（HPF）が必要.

(4) $0.25 \mathrm{~Hz}$ の固有振動に注意する.

\section{3. 交流動作のための増幅器 233}

\section{1 增幅の方式}

$0.1 \sim 0.3 \mathrm{~Hz}$ のような超低周波の信号を，アナログ的安定に 測定・表示しようとすると，系の時定数がきわめて大きくなって 测定が実用的でなくなるので，ディジタル的な測定回路を用いる ことにした. 図 5 にそのブロックダイアグラムを示す.

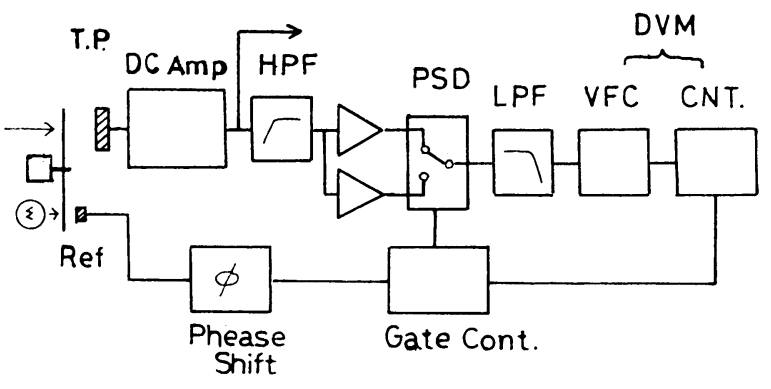

图 5 增幅・検波システムのブロックダイアグラム

サーモパイルからの断続交流信号は, 直流增幅器（これまでサ ーモパイルの直流増幅に使用していたもの, 高域しゃ断周波数約 $0.7 \mathrm{~Hz}$ ）を経て低域しゃ断フィルタにはいり, 直流分と $1 / \mathrm{f}$ 雑音 をしゃ断して検波（整流）される. 検波器は同期検波方式で，チ ョッパからの参照信号で水銀リレーを駆動して, 全波整流を行な 5. 整流出力は簡単な高域しゃ断フィルタを経てディジタル積分 器 (VF コンバータとカウンタ) にはいる. ディジタル積分器の ゲートは, 同期整流器と連動して信号周期 $T$ (リセット時間 $\Delta T$ を含む) の間 ONとなって，一周期の信号を積分して表示する （図 6).このような方式にすると信号は一周期ごとに計数表示さ 


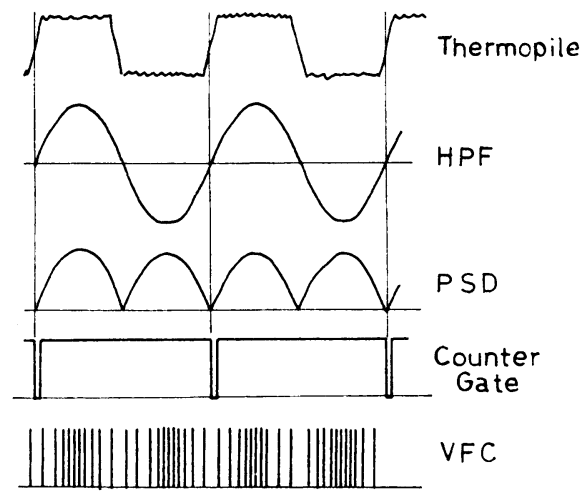

図 6 增幅・㭘波システム各部の信号波形

れ，周波数 $0.1 \sim 0.3 \mathrm{~Hz}$ ならば $10 \sim 3.3 \mathrm{~s}$ おきにサンプリングし た結果が得られるので, 応答速度はフィルタ回路だけが問題にな る.

なお，この系ではチョッパを動作させない状態で直流増幅器の 出力を測定して, 直流動作で入射を求めておき（サーモパイルは 直流動作で校正されている), 引き続いてチョッパを動作させて 交流出力が測定できるので, 交流動作の感度を容易かつ正確に求 めることができる.

\section{2 フィルタの特性}

$1 / \mathrm{f}$ 雑音のしゃ断には，低域しゃ断フィルタ（HPF）が有効で あり, 一方, サーモパイルと直流増幅器は高域しゃ断特性を持つ ので, これらの組久合わせで，増幅系全体は帯域フィルタの機能 を持つことになる。したがって， HPF の特性は系全体の周波数 特性が，チョッピング周波数を中心とした带域特性になるように 選定する必要がある。また，しゃ断特性をシャープにしすぎると 時間的な応答が悪化するので，予借実験を行なって減衰特性 12 $\mathrm{dB} / \mathrm{OCT}$ ，程度が適当であることを見いだした。図 7 に試作し

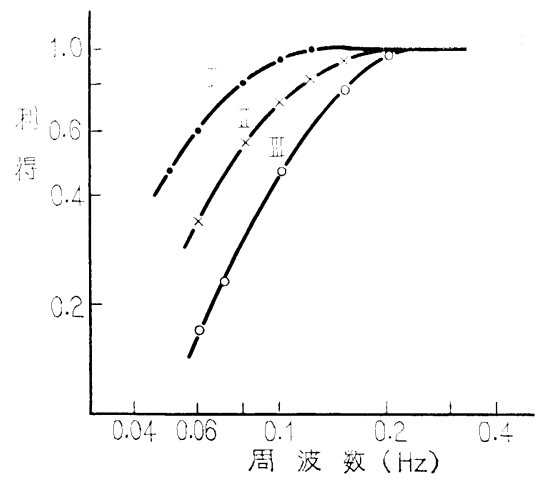

图 7(a) 低域しゃ断フィルタの特性

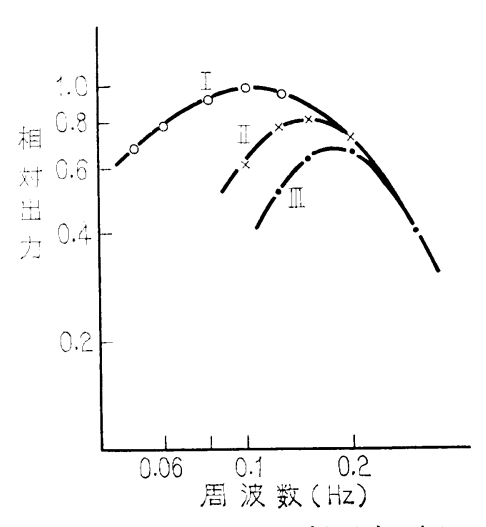

图 7(b) 低域しゃ断フィルタ（I～III）と組み 合わせたサーモパイルの周波数特性
た HPF の特性と, サーモパイル, 直流増幅器を含めた系全体の 周波数特性を示す. 図 5 の同期整流器の後の高域しゃ断フィルタ （LPF）はしゃ断周波数 $0.2 \sim 0.4 \mathrm{~Hz}$ （時定数 $1 \sim 0.5 \mathrm{~s}$ ）で，整 流に伴う雑音を抑制して積分の精度をよくするのに効果がある.

\section{4. サーモパイル交流動作特性の測定}

表 1 の定格のサーモパイルを直流動作, および前述した増幅系 で交流動作させたときの特性を以下に示す。サーモパイルは直流 動作では，周囲の騒乱（風，振動など）の影響をきわめて受けや すいので，測定はすべて無風に近い状態で，振動などの影響をさ けて行なった。 また，室内のわずかな気流の乱れも雑音になるの で，サーモパイルは木箱に入れてしゃへいして周囲温度も極力一 定に保った. しかし交流動作にすると気流と温度の影響はほとん ぞ除去できることがわかったので，交流動作時は木箱によるしゃ へいは行なわなかった。

\section{1 検出能力 (感度と雑音) ${ }^{4) 5}$ )}

前述の(1)式で定義した感度, および雑音の入射パワ一換算值 （NEI）を測定した．NEI は直流動作では(2)式，交流動作では(3) 式によった.

$$
\begin{aligned}
\mathrm{NEI}_{d c}=\frac{E_{p-p}}{V_{d c}} \cdot \frac{\Delta V_{r m s}}{\sqrt{\Delta f}} & \left(\mu \mathrm{W} \cdot \mathrm{cm}^{-2} \cdot \mathrm{Hz}^{-1 / 2}\right) \cdots \cdots(2) \\
\mathrm{NEI}_{a c}=\frac{0.5 E_{p-p}}{V_{r m s}} \cdot \frac{\Delta_{r m s}}{\sqrt{\Delta f}} & \left(\mu \mathrm{W} \cdot \mathrm{cm}^{-2} \cdot \mathrm{Hz}^{-1 / 2}\right) \cdots \cdots(3)
\end{aligned}
$$

ここで， $E_{p-p}$ は入射の放射照度の $\mathrm{ON}-\mathrm{OFF}$ 幅, $\Delta V_{r m s}$ は指 示のゆらぎ（指示計器：DVM）の標準偏差である. $\Delta f$ は測定系 の雑音帯域幅で，直流動作では指示 DVM の積分ゲート時間（4 s）の逆数である. 交流動作では交流增幅部帯域 $\Delta f_{a}$ 之直流増 幅部帯域 $\Delta f_{d}$ の合成で，通常は $\Delta f_{d} \gg \Delta f_{a}$ のため $\Delta f_{a}$ を無視す るが，この測定系では $\Delta f_{a} \simeq 2 \Delta f_{d}$ なので合成带域幅 $\Delta f$ は $\Delta f_{a}$ （積分時間 $T$ の逆数）の 0.7 倍程度となった.

感度の測定は，入射 $50 \sim 80 \mu \mathrm{W} \cdot \mathrm{cm}^{-2}$ のレベルで行ない(八口 ゲン電球使用), NEI は暗状態のゆらぎから求めた．NEI を求め るための $\Delta V_{r m s}$ は, 暗出力 5 点の読みの標準偏差を 1 組のデー タとした10６0組の幾何平均である。な増幅系自身の雑音は無 視できた.

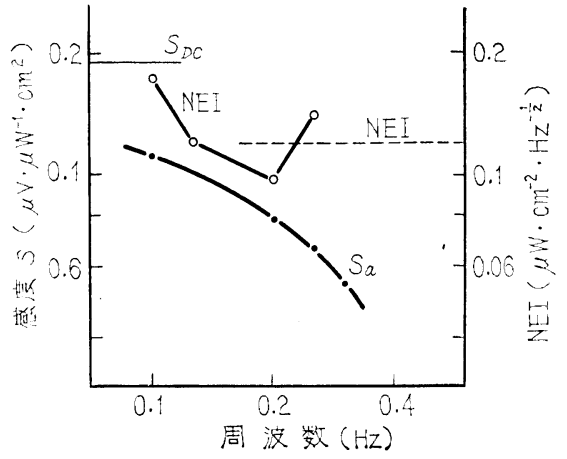

図 8 感度と雑音の入力換算值 (NEI) の周波数特性

測定結果は図 8 のと打りで, 感度は周波数の上昇につれて低 下するが，NEI は周波数 $0.2 \mathrm{~Hz}$ 付近で最小で直流動作よりも良 好であって，したがって $\mathrm{S} / \mathrm{N}$ は $0.2 \mathrm{~Hz}$ 付近で最良になる. 感度 の低下は増幅器の利得增加で十分カバーできるので, 結局, 交流 動作はチョッピング周波数 $0.2 \mathrm{~Hz}$ 付近で, ドリフトのない状態 での直流動作を上回る検出能力が得られることになる. 


\section{$4.2 ト$ リ フ}

交流動作のドリフトはきわめて少なく，周波数 $0.2 \mathrm{~Hz}$ のとき 数十分について雑音の幅以下であって，測定室内を空調してもそ の影響はほとんどなく，空調の有無で NEI に有意な差を認める ことはできない。

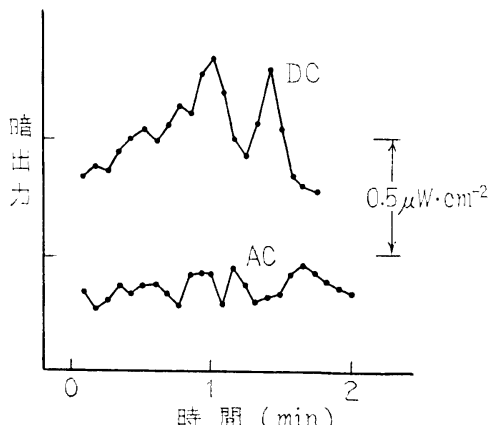

(a)

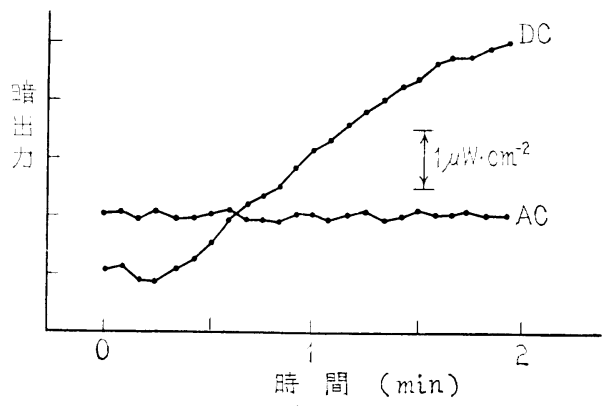

(b)
图 9 ドリフトの交流動作，直流動作比較

（a）空調なし，やや風あり（b）空調実施，無風

これに対して直流動作では, わずかの温度変化でも雑音振幅の 多”倍のドリフトが生じ，空調実施時のドリフトの幅は入力值換算 で $、 \mu \mathrm{W} \cdot \mathrm{cm}^{-2}$ (雑音の 100 倍）飞達 し, 変化率は最大 $2 \mu \mathrm{W} \cdot$ $\mathrm{cm}^{-1}$ nin になるので測定の重大な障害となることが多い. 図 9 にやや，度変化のある状態（空調なし）と，空調を実施した状態 での直流，交流両動作のドリフト（暗状態）を図 5 に示した測定 系で同時測足した結果を示す. 交流動作の安定性は明らかで, 雑 音, ドリフトを総合して交流動作が全く有利なことがわかる.

\section{3 直線性}

入射放射照度比 $10 ： 1$ 亿ついて, 出力の直線性テストをメッシ ュスクリーン減光板によって, 直線性既知のシリコンホトセルと 比較しながら，周波数 $0.1 \mathrm{~Hz}, 0.2 \mathrm{~Hz}$ で行なった結果を図 10 に示す． $0.1 \mathrm{~Hz}, 0.2 \mathrm{~Hz}$ ともに10：1 での直線性からのはずれ は幅 $1 \%$ 以内であって，問題はないと考学られる.

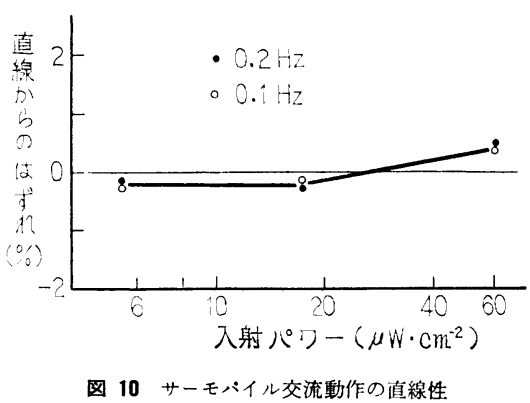

\section{4 受光面の感度の一様性}

$150 \mathrm{~W}$ ハロゲン電球から約 $100 \mathrm{~mm}$ はなして $1 \phi$ のピンホール
をおき， $\mathrm{f}=150 \mathrm{~mm}$ の色消しレンズでサーモパイルの受光面上に 等倍のスポットを投影して, これを受光面内で垂直, 水平方向に ほほ $1 \mathrm{~mm}$ 扣きに移動して感度の分布状態を測定した.なお、レ ンズの近傍に赤外カットフィルタを打いて，可視放射だけが入射 するようにした，入射パワーは約 $25 \mu \mathrm{W}$ である.

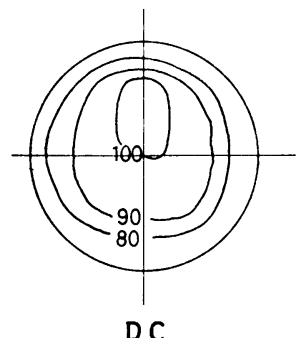

DC

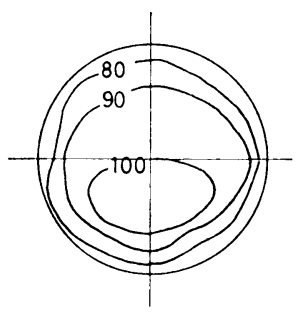

$0.1 \mathrm{~Hz}$

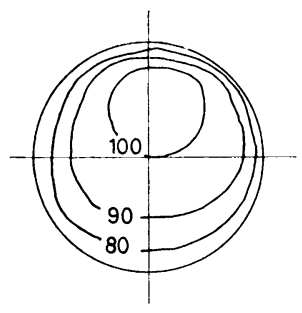

$0.2 \mathrm{~Hz}$
図 11 受光洎の感度分布

測定結果を等感度図として図 11 亿示す．直流， $0.1 \mathrm{~Hz}, 0.2$ $\mathrm{Hz}$ でそれぞれ最大感度位固の変動が見られるが, 不均一さはい ずれも $10 \%$ 程度で，一様性としては大差ないことがわかる.な お， Stair らは交流動作時にサーモパイル受光面の感度分布が大 幅に変動する例を報告している7)。この実験では周波数がきわめ て低いこともあって，そのような現象は認められなかったが，周 波数によって分布に多少の変化は生じており，黑化材（金黒）の 局部的な熱伝導の異なりなどが，その原因の一つであると考えら れる.

\section{5 温 度 特 性}

サーモパイルの感度は, 一般に $-0.1 \sim-0.4 \% /{ }^{\circ} \mathrm{C}$ の温度係数 を持つとされている ${ }^{6)}$.この垁験に用いた試料, 直流動作での温 度係数は周囲温度 $16 \sim 24{ }^{\circ} \mathrm{C}$ でー $0.4 \% /{ }^{\circ} \mathrm{C}$ であった. 交流動作で 温度俰数を測定した結果は, 周波数 $0.2 \mathrm{~Hz}$ で周囲温度 $19 \sim 29^{\circ} \mathrm{C}$ のときに一 $0.15 \% /{ }^{\circ} \mathrm{C}$ となて, 直流動作より良好な結果が得ら れている.この理由は明らかでない，温度特性は室温全体を変化 させ, 温度平衡に達したことを確認して測定している。

\section{6 応答の時間的特性}

約 $45 \mu \mathrm{W} \cdot \mathrm{cm}^{-2}$ のステップ入射を与えたときの忘答特性を, 直 流動作と周波数 $0.2 \mathrm{~Hz}, 0.1 \mathrm{~Hz}$ の交流動作について求めた結果 を図 12 示にす. 出力が定常值の $99 \%$ に達するまでの時間は直流 動作では約 $12 \mathrm{~s}$ であるが，交流動作では周波数 $0.2 \mathrm{~Hz}$ で $25 \mathrm{~s}$ ， $0.1 \mathrm{~Hz}$ では $30 \mathrm{~s}$ であり直流動作の $2 \sim 2.5$ 倍である.この遅れの

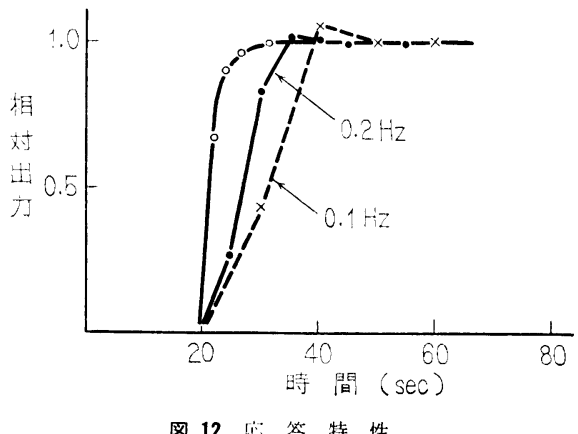

原因は主として低域しゃ断フィルタの時定数と思われる。しか し，実際使用にあたっては交流動作はドリフトがほとんどなく， 直流動作での使用のように，測定 1 回ごとに入射を ON-OFF し てゼロチェックをする必要がないので，応答の遅れによって測定 時間が大幅に増加することはない。 


\section{5. 実用テスト結果}

チョッピング周波数 $0.2 \mathrm{~Hz}$ で, モノクロメータからの 単色光 をサーモパイル（定格は表 1 参照）へ入射させて, 受光器の分光 感度測定を行なら状態で, 空調実施状態での安定性と再現性を測 定した. モノクロメータの出射単色光の波長は $390 \sim 760 \mathrm{~nm}$ で, 受光面の放射照度は $0.5 E_{p_{-} p}$ で $3 \sim 11 \mu \mathrm{W} \cdot \mathrm{cm}^{-2}$ である. 出射単 色光の放射照度分布を均せい化するために, 光ファイ バ光ガイ ド8) (素線径 $0.25 \mathrm{~mm}$ の束, プラスチック)をと扎して受光面を 照射し, 均せい度を $90 \%$ 以内にしてある.モノクロメータは G250 で, 単色光の半值幅は $6.7 \mathrm{~nm}$ 一定, 光源は $\mathrm{JC} \cdot 24 \mathrm{~V} \cdot 150$ $\mathrm{W}$ ハロダン電球 ( $22 \mathrm{~V}$ 点灯) で, $\mathrm{f}=38 \mathrm{~mm}$ の石英単玉レンズで 集光入射している.

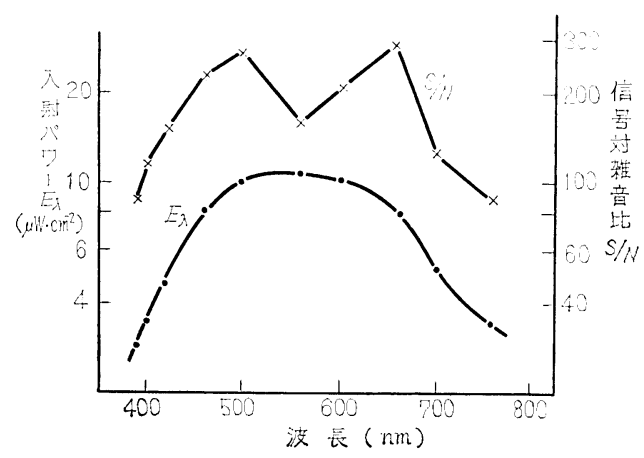

图 $130.2 \mathrm{~Hz}$ の交流動作で分光測定に用いた

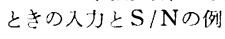

図 13 に波長 $390 \sim 760 \mathrm{~nm}$ の受光面入射と $\mathrm{S} / \mathrm{N}$ の一例を示 ナ. S/Nは(4)式で計算した.

$$
\mathrm{S} / \mathrm{N}=\frac{\bar{V}_{E}}{\sqrt{\Delta V_{D}^{2}-\Delta V_{E}^{2}}}=\frac{\bar{V}_{E}}{\Delta V_{N}}
$$

ここで, $\bar{V}_{E}$ は照射時の読みの平均と暗状態の読みの平均の差, $\Delta V_{E}$ と $\Delta V_{D}$ は, それぞれ暗状態と照射時の読みの標準偏差であ る*. 読みの数は各々 5 回である. 測定の不確かさは $\mathrm{S} / \mathrm{N}$ の逆数 と考光てょく, 四 13 の場合では $\pm 0.33 \sim 1.1 \%$ になる. $\Delta V_{N}$ の 雑音帯域幅 $1 \mathrm{~Hz}$ 当たりの值 $\Delta V_{N} / \sqrt{\Delta f}$ は，入射に換算して1.1 $\times 10^{-7} \mathrm{~W} \cdot \mathrm{cm}^{-2}$ で, 4.1 で求めた NEI よりわずかに大きい.こ のような測定を 6 回行なったときのばらつきを図 14 に示す.

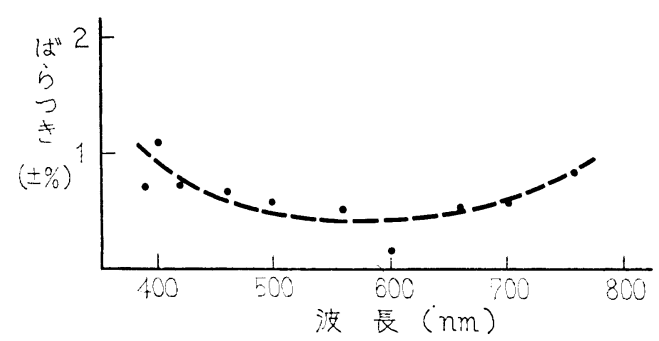

図 14 分光測定を 6 回行なったときの相対値の再現性

これは, 各々 1 回の測定の読みの総平均值で, 規格化した相対 值**の間の標準偏差である.このばらつきは土 $1 \%$ 以内にはいっ ている. 6 回の測定は 1 回ごとにサーモパイルを取りはずして再

* 普通 $\mathrm{S} / \mathrm{N}$ は $V_{E} / \Delta V_{E}$ としている. しかし最終的に用いる值は照射時と暗状態 の羙であるから，暗状態の雑音を加算すべきである.

***夂各々の測定の波長ごとの値を $V_{\lambda 1}, V_{\lambda 2}, \cdots \cdots V_{\lambda n}$ として，それらを $\Sigma V_{\lambda} / n=\bar{V}$ で規格化した值, 各回ごとに $\bar{V}=1,000$ とする.
セットして拈り, 絶対値のばらつきは $\pm 2.5 \%$ 程度であった。 こ れは主として位置の再現の不確かさによると思われる。

この 6 回の測定は 3 日にわたって行ない, 空調による温度変動 は土 $1{ }^{\circ} \mathrm{C}$ 程度であったが, 相対值の再現の幅はほぼ雑音の幅に おさまっていて, 直流動作時に比べて安定性, 再現性は格段に良 好になっていることがわかった。な拉，1回（10波長）の測定に 要する時間は約 25 分で, 直流動作㭙の $2 / 3$ 以下に短縮することが できた.

\section{6. 結 び}

従来, 直流的に用いられていた受光面積の大きいサーモピイル の交流での使用を検討して，感度および雑音の周波数特性を吟味 して適正なチョッピング周波数を見いだし，増幅・検波にはディ ジタル積分形の同期検波回路を用いて，実用的で精度の高い測定 を可能とした。

交流動作によってドリフトは事実上ゼロとなり, 室内の気流の 乱れなどによる騷乱にも安定となって，しゃへいヶースなしで空 調使用下でも数 $\mu \mathrm{W} \cdot \mathrm{cm}^{-2}$ の入射の精密測定が行なえるようにな った. 交流動作では見かけの感度は低下寸るが，チョッピング周 波数の選択, 増幅器の带域幅の制御によって雑音を低減させて, 直流動作での理想的な使用状態と同等以上の検出能力が得られ た. 直線性, 受光面の感度の均一性も直流動作時との差はみられ ず，温度特性は直流動作時より良好であった，交流動作での応答 時間は直流動作時の $2 \sim 2.5$ 倍遅くなる.しかし，ドリフトによ るゼロ点移動がないので，入射の ON-OFF をひんぱんにする必 要がなく, 応答の遅れは央用的にはそれほど障害にはならない。

放射の絶対感度を, 交流動作の検出器に直接に目盛付けること は一般に精度上の困難があるが，本報の方法によると測定系を指 示計器接続点の切り換えだけで交直両用にできるので, 動作を 交・直交互として，一つのサーモパイルで直流動作を standard に, 交流動作を reference として, 交流動作に目盛り付けができ るので絶対測定を容易に行なうことができる.

以上, 受光面積, 時定数の大きなサーモパイルが交流的に使用 することができ，それによって検出器としての諸特性をそこねる ことなく, 直流動作時に問題となっていた取扱い上の欠点をほぼ 解消できることを示した．今後さらに使用条件を検討して，検出 能力, 安定性の一層の向上をはかるべきであると考えている.

\section{文献}

（1）伊藤和喜：電総研調查報告 No. 177 （昭48）第 5 章

(2) 内田, 南: 分光研究 23 (昭49) 196

（3）横井与次郎：リニア実用回路マニアル（昭50）ラジオ技術 社 第 7 章

(4) R. C. Jones: Proc. IRE 47 (1959) 1481, 95

(5) C. Motchenbacher, F. Fitchen, 斉藤ほか訳 : 低雑音電子 回路の設計 (1977) 近代科学社 第 1 章, 第 7 章

(6) CIE Wasington (1967) E-1.2 Appendix 1, Eppley 社 カタログ

(7) R. Stair et. al.: Appl. Optics 4 (1965) 703

（8）中川, 大谷：昭55照明学会全国大会94（昭55）

（受付1980年 9 月 5 日） 